\title{
Adsorption-Desorption of BTX (Benzene, Toluene and 0-Xylene) on Fe, Fe-Al Pillared Clay
}

\author{
Zohra Mèçabih \\ Laboratory of Materials and Catalysis, Department of Chemistry, Faculty of Exact Sciences, University of Djillali Liabes, Sidi Bel \\ Abbes, Algeria \\ Email: zmecabih@gmail.com
}

How to cite this paper: Mèçabih, Z. (2017) Adsorption-Desorption of BTX (Benzene, Toluene and O-Xylene) on Fe, Fe-Al Pillared Clay. Journal of Encapsulation and Adsorption Sciences, 7, 40-66. https://doi.org/10.4236/jeas.2017.71003

Received: January 5, 2017

Accepted: March 3, 2017

Published: March 6, 2017

Copyright (C) 2017 by author and Scientific Research Publishing Inc. This work is licensed under the Creative Commons Attribution International License (CC BY 4.0).

http://creativecommons.org/licenses/by/4.0/

Open Access

\begin{abstract}
The studies are conducted in laboratory to determine the adsorption-desorption behavior of BTX (benzene, toluene and o-xylene) in gas phase on $\mathrm{Fe}$, $\mathrm{Fe}-\mathrm{Al}$ pillared clays adsorbents. In experimental conditions of constant atmospheric pressure, initial concentrations with an increasing volume (0.5 - 2 $\mathrm{ml}$ ) injected benzene (2.25), toluene (1.89) and o-xylene (1.66) $\mu \mathrm{mol} / \mathrm{L}$ at T $\left(40^{\circ} \mathrm{C}, 60^{\circ} \mathrm{C}\right.$ and $\left.80^{\circ} \mathrm{C}\right)$, and the adsorption increases with increase of temperature, indicating that the adsorption process would be a chemical adsorption rather than physical one. The results are shown that the BTX adsorption data fitted very well $\left(R^{2}>0.999\right)$ to the both equations Langmuire and Elovitch for the three samples: bentonite (B), Fe-bentonite ( $\mathrm{Fe} / \mathrm{B})$ and $\mathrm{Fe}-\mathrm{Al} /$ bentonite $(\mathrm{Fe}-\mathrm{Al} / \mathrm{B})$. At $80^{\circ} \mathrm{C}$, the BTX adsorption capacity increased in the following order: $\mathrm{B}<\mathrm{Fe} / \mathrm{B}<\mathrm{Fe}-\mathrm{Al} / \mathrm{B}$. The maximum adsorption capacity $\left(q_{m}\right)$ at $80^{\circ} \mathrm{C}$ is $175.13,171.84$ and $171.81 \mu \mathrm{g} / \mathrm{g}$ respectively for benzene, toluene and o-xylene for $\mathrm{Fe}-\mathrm{Al} / \mathrm{B}$; the last is a good adsorbent of BTX removal. The benzene diffuses faster than toluene and o-xylene. Thermodynamic parameters, such as $\Delta G^{\circ}, \Delta H^{\circ}$ and $\Delta S^{\circ}$ are also discussed and the results suggested that the BTX adsorption on all samples used is a spontaneous and endothermic process. Desorption studies show that BTX is very easily desorbed with $\mathrm{Fe}-\mathrm{Al} / \mathrm{B}$.
\end{abstract}

\section{Keywords}

Fe, Al-Pillared, Benzene, Toluene, O-Xylene, Adsorption

\section{Introduction}

The natural gas and oil industry activities are known for some time to create harmful air emissions that emit volatile organic compounds (VOCs) and oxides of nitrogen $\left(\mathrm{NO}_{X}\right)$, which are precursors to tropospheric ozone. The major 
VOCs, the benzene, toluene and xylene (BTX) volatile compounds are significant environmental concern and are listed as priority pollutants by the United States Environmental Protection Agency (US EPA) [1] because of their toxic and carcinogenic effects on humans. Besides, the benzene is already known as the leukemia agent in humans [2]. Another, VOCs characterized by their photochemical activity could undergo a series of photochemical reaction to from the secondary organic aerosol, which is one of the major components of airborne fine particles. The VOCs cause environmental concerns about their toxicity and malodor, even at very low concentrations, due to the obvious impacts on atmosphere and human health; it is necessary to limit and control this air emission. The difficulty, for decreasing the VOCs in gas phase at very low concentrations, requires a highly optimized process. Various processes can be used for abatement of VOCs which are broadly classified into two types: destruction (biofiltration, thermal oxidation, catalytic oxidation, reverse flow reactor) and recovery (adsorption, condensation, membrane separation) [3]. The adsorption by solid adsorbents is one of the best solutions for this treatment; the choice of adsorbent depends on these adsorptive properties and availability. Granular or powdered actived carbon is the most widely used adsorbent [4], but their use is usually limited due to their high cost. Over several decades, many researchers show their interests in searching for low-cost adsorbents with excellent adsorption characteristics, such as zeolites [5], organokaolinite [6], smectite [7], hectorite [8], organosilica [9], and montmorillonite [10] [11]. The pillared interlayer clay (PILC) attracts attention of many researchers, and constitutes one of the most widely studied series among the microporous materials with a wide range of potential applications in adsorption processes. PILCs are formed by insertion of polynuclear inorganic cation into their interlayer space, followed by calcinations to give stable metal oxide pillars (e.g. $\mathrm{Al}_{2} \mathrm{O}_{3}, \mathrm{Fe}_{2} \mathrm{O}_{3}$ etc.) having larger micropores. The purpose of this paper is to present the effectiveness of (Fe, Fe-Al)-pillared bentonite clay adsorbents to reduce the concentration of BTX and determine behavior of BTX with evaluating the influence of the temperature on BTX adsorption. Adsorption isotherm is measured at three different temperatures: $40^{\circ} \mathrm{C}, 60^{\circ} \mathrm{C}$ and $80^{\circ} \mathrm{C}$.

\section{Materials and Methods}

\subsection{Materials}

The natural clay used in this work is a bentonite type from Maghnia (west Algerian). It is supplied by the Algeria Bentonite Company (ENOF). The natural bentonite is purified in laboratory [12] [13], using a sedimentation method to obtain the $<2 \mu \mathrm{m}$ montmorillonite rich faction. The carbonates are removed by sodium acetate/chloridric acid, iron oxide by sodium thiosulfate/sodium chloride and organic materials by hydrogen peroxide ( $30 \%$ vol.). To ensure complete transformation into the sodium from all samples, they are washed several times with $0.5 \mathrm{M} \mathrm{NaCl}$. The exchange capacity or CEC $91 \mathrm{meq} / 100 \mathrm{~g}$ (by methylene bleu exchange). 


\subsection{Preparation of Hydroxyl-Al}

The pillaring solution of $\mathrm{Al}$ and Fe polycation are prepared separately [13]. 0.207 $\mathrm{M} \mathrm{NaOH}$ solution is added slowly while stirring to a $0.207 \mathrm{M} \mathrm{AlCl}_{3}$ solution until it reached an $\mathrm{OH} / \mathrm{Al}^{3+}$ molar ratio of 2.5 in the mixture. The mixture is aged at room temperature during 6 days at room temperature.

\subsection{Preparation of Hydroxyl-Fe}

Fe polycations solution is prepared by slowly adding a $0.1 \mathrm{M} \mathrm{NaOH}$ solution to $0.1 \mathrm{M} \mathrm{FeCl}_{3}$ solution under vigorous stirring, until the $\mathrm{OH} / \mathrm{Fe}^{3+}$ ratio reaches the value 2.5. The mixture is aged for two weeks at room temperature [13].

\subsection{Preparation of Fe-Al Pillared Bentonite}

The pillaring solution containing hydroxyl-Al oligocations and hydroxyl-Fe oligocations are slowly added under vigorous stirring into the suspension purified bentonite while, until the mass ratio of $\mathrm{M}^{3+}\left(\mathrm{M}^{3+}=\mathrm{Fe}^{3+}, \mathrm{Al}^{3+}\right) /$ caly reached 6.25\% [13]. The solids are filtered and washed with deionized water until it are free of $\mathrm{Cl}^{-}$ions. The solids $\mathrm{B}, \mathrm{Fe} / \mathrm{B}$ and $\mathrm{Fe}-\mathrm{Al} / \mathrm{B}$ are calcined for $2 \mathrm{~h}$ at $300^{\circ} \mathrm{C}$ ground and sieved.

High-purity BTX: benzene (99 wt.\%, Aldrich), toluene (99.5 wt.\%, Aldrich) and o-xylene (99 wt.\%, Aldrich) are used absorbate.

\subsection{Characterization}

The Analysis of the chemical composition of the purified bentonite is obtained fluorescence $X$. The surface area is measured with a Micromeritics ASAP 2010 instrument by adsorption of nitrogen at $77 \mathrm{~K}$. Before measurement, the samples are degassed under vacuum of $20.8 \mathrm{~Pa}$ at $120^{\circ} \mathrm{C}$ for 2 .

\subsection{BTX Adsorption Kinetics}

$1 \mathrm{~g}$ of the samples in the nacelle is placed in glass enclosure $(10 \mathrm{~L})$, closed and thermostated degassed for $2 \mathrm{~h}$ using the means of a water-jet pump. Then, $2 \mathrm{ml}$ of BTX (benzene, toluene and o-xylene) containing respectively, 2.25, 1.89 and $1.66 \mu \mathrm{mol} / \mathrm{L}$ is sprayed into the enclosure by injection (Figure 1). After, the nacelles are removed from the enclosure and the samples are weighed. The experiments are carried out at $40^{\circ} \mathrm{C}, 60^{\circ} \mathrm{C}$ and $80^{\circ} \mathrm{C}$ in a temperature controlled bath (Figure 1).

\subsection{Equilibrium Isotherm}

$1 \mathrm{~g}$ of the samples in the nacelle is placed in glass enclosure $(10 \mathrm{~L})$, closed and thermostated degassed for $2 \mathrm{~h}$ using the means of a water-jet pump. Then, different volume ranging from $(0.5-2 \mathrm{ml})$ is sprayed into enclosure by injection of liquid BTX: benzene, toluene and $o$-xylene with initial concentration respectively $2.25,1.89$ and $1.66 \mu \mathrm{mo} / \mathrm{L}$. The experiments are carried out at $40^{\circ} \mathrm{C}, 60^{\circ} \mathrm{C}$ and $80^{\circ} \mathrm{C}$ in a temperature controlled bath (Figure 1 ). After reaching the adsorption equilibrium, the nacelles are removed from the enclosure and the samples 


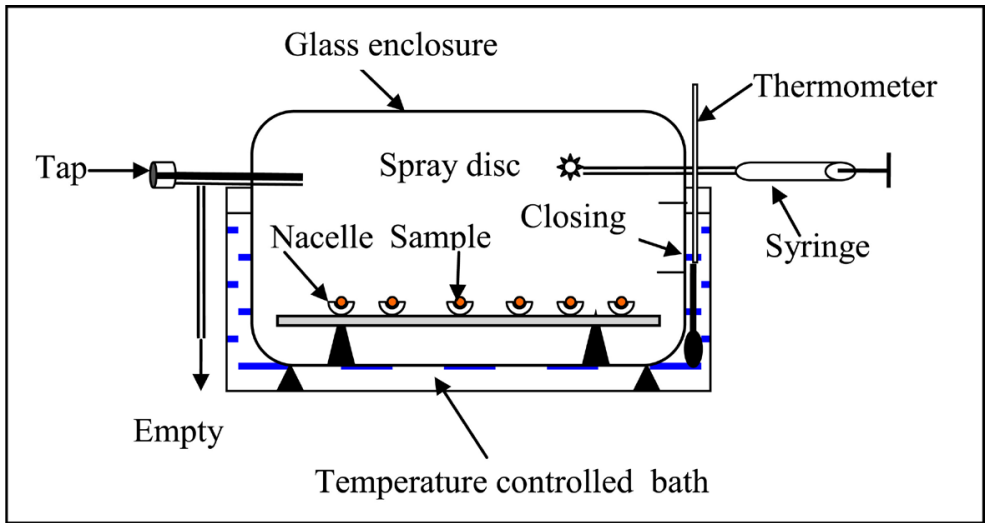

Figure 1. Experimental set-up for the adsorption of the BTX.

weighed by Sartorius 1219 MP balance type (accuracy $\pm 10^{-3} \mathrm{~g}$ ). The amount of adsorbed BTX on adsorbents $\left(q_{e} \mu \mathrm{g} / \mathrm{g}\right)$ is calculated as follows:

$$
q_{e}=\frac{\left(C_{0}-C_{e}\right) \cdot V}{m}
$$

where $C_{0}$ and $C_{e}$ are the initial and equilibrium BTX concentrations $(\mu \mathrm{g} / \mathrm{L})$, respectively; $V$ is initial liquid volume (L) equal to glass enclosure volume; and $\mathrm{m}$ is the adsorbent weight $(\mathrm{g})$.

\subsection{Desorption Experiments}

For desorption experiments, the nacelle in glass enclosure is subjected before to degassing for $2 \mathrm{~h}$ at constant pressure. $1 \mathrm{~g}$ of the samples are saturated in benzene, toluene and $o$-xylene of concentration $2.25,1.89$ and $1.66 \mu \mathrm{mol} / \mathrm{L}$ respectively are desorbed for $2 \mathrm{~h}$ and at temperature $T\left(40^{\circ} \mathrm{C}, 60^{\circ} \mathrm{C}\right.$ and $80^{\circ} \mathrm{C}$ ) (Figure 1). The amounts of BTX retained are obtained from the difference between the initial concentration $\left(C_{0}\right)$ and the final concentration $\left(C_{t}\right)$, desorption rate is calculated as from Equation (2):

$$
\tau=\frac{\left(C_{0}-C_{t}\right)}{C_{0}} \cdot 100
$$

\section{Results and Discussion}

\subsection{Characterization of the Adsorbent}

The chemical composition of purified bentonite by X-ray fluorescence is reported in Figure 2, the results collected in Table 1 showed the silica to alumina ration $\left(\mathrm{SiO}_{2} / \mathrm{Al}_{2} \mathrm{O}_{3}\right)$ confirms the montmorillonite variety as an almost exclusive component of our purified clay.

The $\mathrm{N}_{2}$ adsorption/desorption isotherm of purified bentonite is shown in Figure 3. The adsorption isotherm is of type IV according to (B.D.D.T) classification, which is generally associated with capillary condensation in mesopore structures, with a well-defined H4 hysteresis loop. This behavior is the indication of a mono-multilayer adsorption on slit-shaped pores among plate-like particles [14]. The opening behaviors of the hysteresis loop indicated the formation 


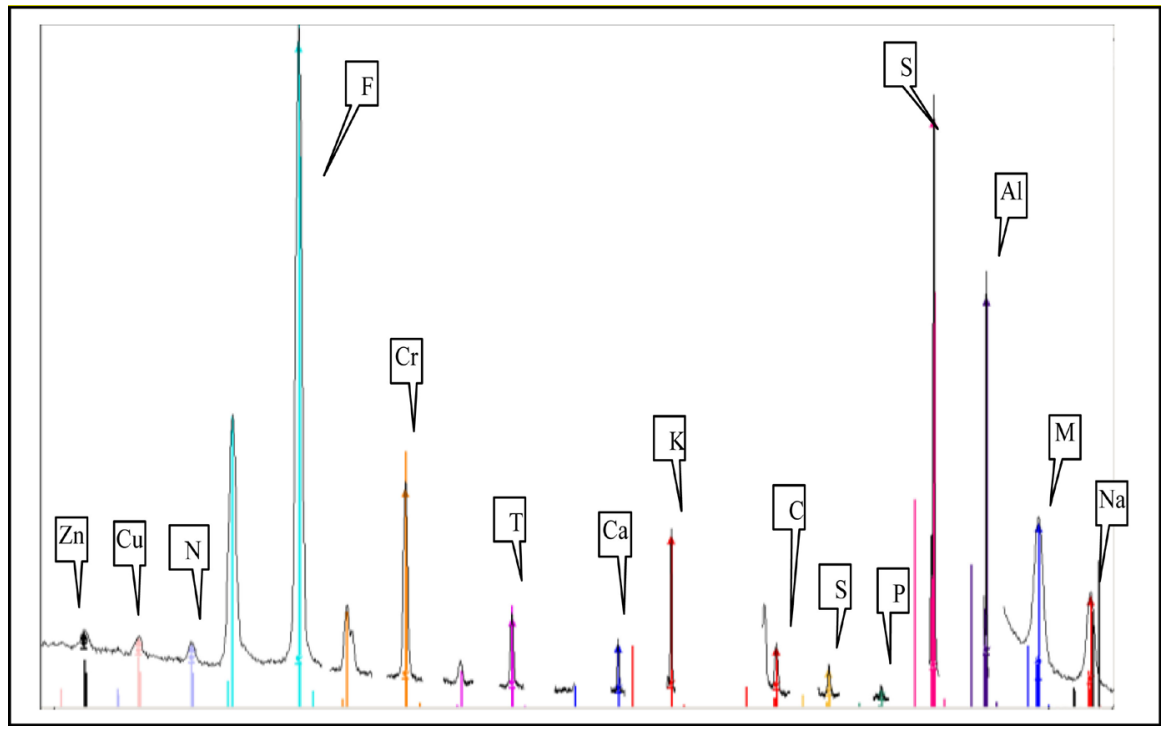

Figure 2. Spectrum of purified bentonite by X-ray fluoresence.

Table 1. Chemical analyses of purified bentonite by X-rays fluorescence.

\begin{tabular}{ccc}
\hline & \multicolumn{3}{c}{ Purified bentonite } \\
\cline { 2 - 3 } Corresponding Oxide & $Z$ & Concentrations \\
\cline { 2 - 3 } $\mathrm{Na}_{2} \mathrm{O}$ & 11 & 3.98 \\
$\mathrm{MgO}$ & 12 & 3 \\
$\mathrm{Al}_{2} \mathrm{O}_{3}$ & 13 & 22.74 \\
$\mathrm{SiO}_{2}$ & 14 & 61.68 \\
$\mathrm{P}_{2} \mathrm{O}_{5}$ & 15 & 0.072 \\
$\mathrm{SO}_{3}$ & 16 & 0.181 \\
$\mathrm{Cl}$ & 17 & 0.282 \\
$\mathrm{~K}_{2} \mathrm{O}$ & 19 & 1.3 \\
$\mathrm{CaO}$ & 20 & 0.192 \\
$\mathrm{TiO}_{2}$ & 22 & 0.349 \\
$\mathrm{Cr}_{2} \mathrm{O}_{3}$ & 24 & 1.1 \\
$\mathrm{Fe}_{2} \mathrm{O}_{3}$ & 26 & 5.175 \\
$\mathrm{NiO}$ & 28 & 0.00892 \\
\hline
\end{tabular}

of irregular shape pores. This opening demonstrated the presence of mesopores in the purified bentonite. The inset of Figure 3 is the pore size distribution of the bentonite purified, in which different volume is plotted against pore size for the desopriton branches of the $\mathrm{N}_{2}$ adsorption/desorption isotherms according to the $\mathrm{BJH}$ model [15]. The results are given in Table 2, for purified bentonite the total pore volume and micropore volume are 0.103 and $0.027 \mathrm{~cm}^{3} / \mathrm{g}$, respectively. The increase of the specific surface area (Table 2) after pillaring with $\mathrm{Fe}, \mathrm{Fe}-\mathrm{Al}$ polycation solutions, suggest also the increasing of the micropores [16].

\subsection{Adsorption Kinetics of BTX on Purified and Pillared Bentonite}

Figure 4 presents the kinetic curves of all samples used at different temperatures. 




Figure 3. $\mathrm{N}_{2}$ adsorption/desorption isotherms and pore size distribution of the purified bentonite.

Table 2. Textural properties of the samples used calcined at $300^{\circ} \mathrm{C}$.

\begin{tabular}{ccccc}
\hline Sample & Specific surface area $\left(\mathrm{m}^{2} / \mathrm{g}\right)$ & Specific surface area $(\mathrm{BJH})\left(\mathrm{cm}^{2} / \mathrm{g}\right)$ & Total pore volume $\left(\mathrm{cm}^{3} / \mathrm{g}\right)$ & Micropore volume $\left(\mathrm{cm}^{3} / \mathrm{g}\right)$ \\
\hline $\mathrm{B}$ & 99.78 & 100.21 & 0.103 & 0.027 \\
$\mathrm{Fe} / \mathrm{B}$ & 177.00 & - & - & - \\
$\mathrm{Fe}-\mathrm{Al} / \mathrm{B}$ & 355.00 & - & - & - \\
\hline
\end{tabular}




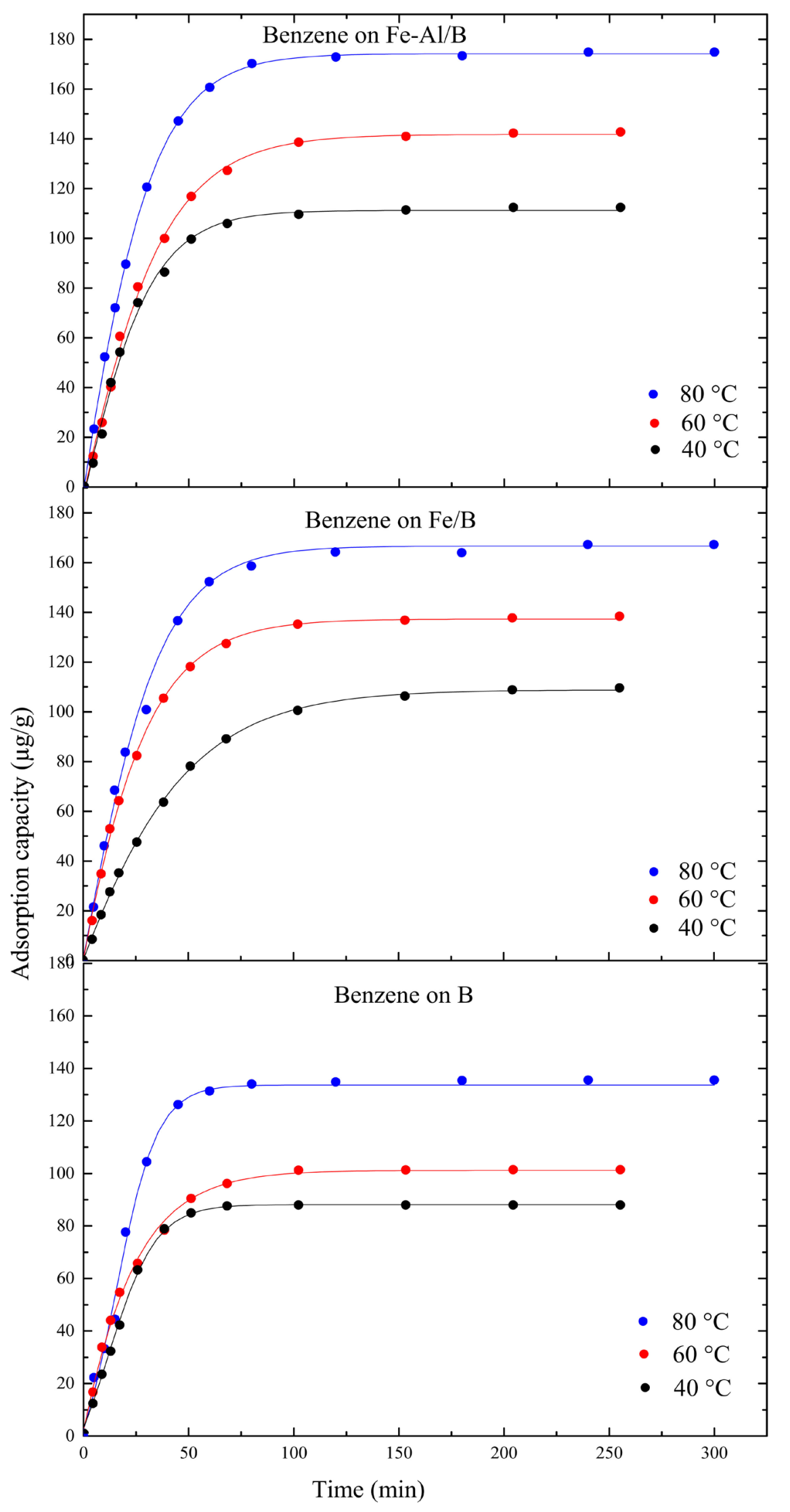




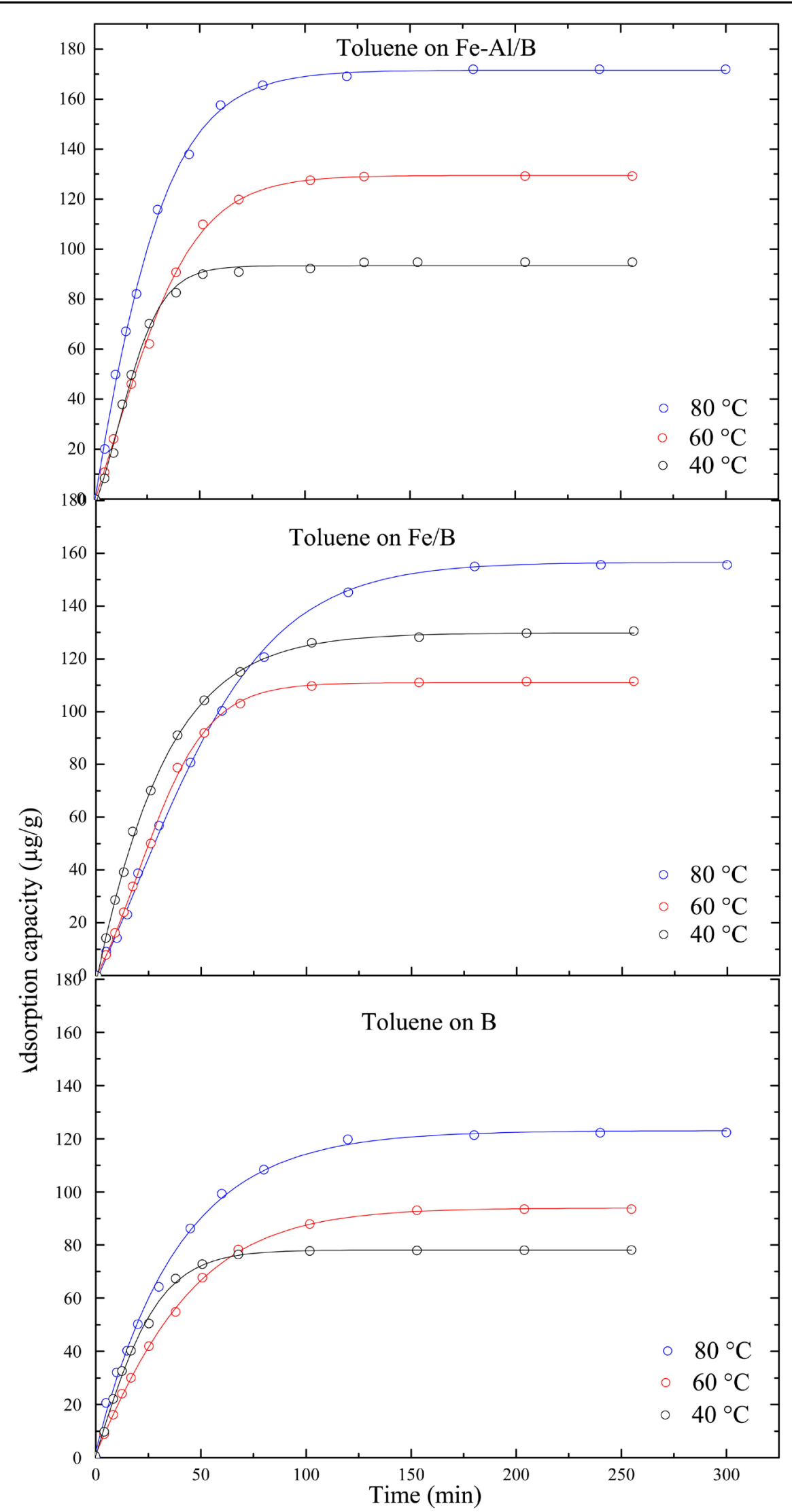




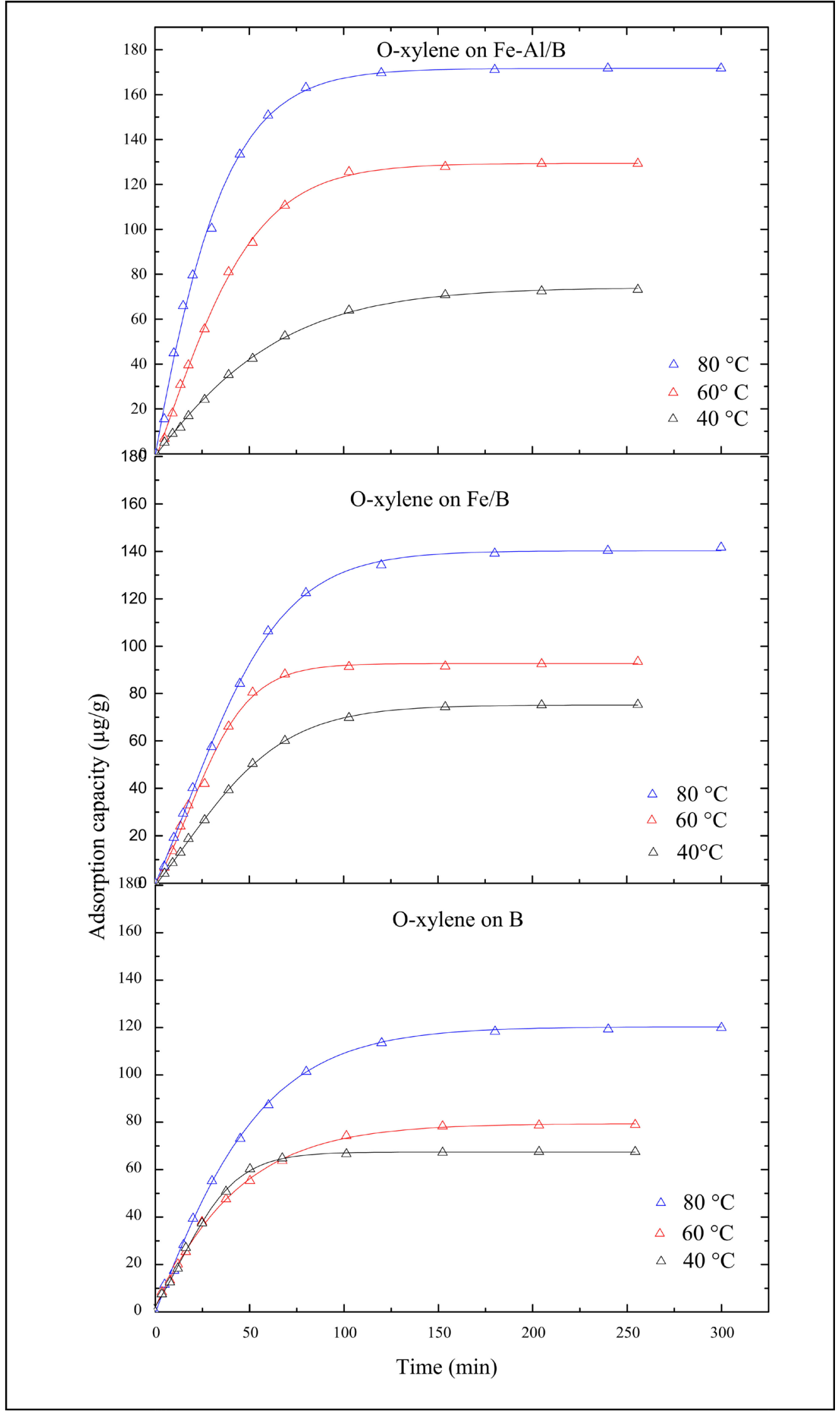

Figure 4. Adsorption kinetics of BTX onto samples used at various temperature. 
It can be seen that the adsorption capacity increased with contact time, quickly in the first $15 \mathrm{~min}$ and then increased gradually with increasing contact time until the adsorption reached adsorption equilibrium at $3 \mathrm{~h}$. It can also be observed that the lower the temperature is, the lower the saturated adsorption capacity is. When the adsorption reached the equilibrium at $80^{\circ} \mathrm{C}$, the adsorption capacity $\left(q_{e}\right)$ is $178.26 \mu \mathrm{g} / \mathrm{g}$ (benzene), $175.50 \mu \mathrm{g} / \mathrm{g}$ (toluene) and $170.56 \mu \mathrm{g} / \mathrm{g}$ (o-xylene) on $\mathrm{Fe}-\mathrm{Al} / \mathrm{B} ; 172.95 \mu \mathrm{g} / \mathrm{g}$ (benzene), $160.15 \mu \mathrm{g} / \mathrm{g}$ (toluene) and $159.76 \mu \mathrm{g} / \mathrm{g}$ (o-xylene) on $\mathrm{Fe} / \mathrm{B} ; 139.70 \mu \mathrm{g} / \mathrm{g}$ (benzene), $121.33 \mu \mathrm{g} / \mathrm{g}$ (toluene) and $119.01 \mu \mathrm{g} / \mathrm{g}$ (o-xylene) on B. Generally, adsorption is exothermic process; the adsorption capacity would be expected to be decreasing with temperature.

The results showed that the adsorption capacity increased with an increase of temperature, indicating the adsorption process is endothermic and the adsorption process would be a chemical adsorption rather than a physical one.

\subsection{Equilibrium Isotherms}

For to assess efficacies for the three adsorbents: $\mathrm{B}, \mathrm{Fe} / \mathrm{B}$ and $\mathrm{Fe}-\mathrm{Al} / \mathrm{B}$; at constant temperature, the quantity of BTX adsorbed onto pillared clay will be in equilibrium with BTX in the gas phase and the adsorption equilibrium data for these adsorbents are fitted by the saturated monolayer isotherm can be represented by Langmuir isotherms:

$$
q_{e}=q_{m} \frac{K_{L} C_{e}}{1+K_{L} C_{e}}
$$

where $C_{e}(\mu \mathrm{g} / \mathrm{L})$ is the equilibrium concentration; $q_{e}(\mu \mathrm{g} / \mathrm{g})$ is the equilibrium amount of BTX adsorbed; $q_{m}(\mu \mathrm{g} / \mathrm{g})$ is a maximum adsorption capacity, $K_{L}$ $(\mathrm{L} / \mu \mathrm{g} /)$ is the adsorption equilibrium constant. Equation (4) can be linearized into the form as follows:

$$
\frac{C_{e}}{q_{e}}=\frac{1}{K_{L} q_{m}}+\frac{C_{e}}{q_{m}}
$$

The results obtained by the applying the Freundlich model is not presented because the low values correlation coefficients $\left(R^{2}<0.99\right)$ show poor agreement of Freundlich isotherm with the experimental data.

The adsorption isotherms are presented in Figure 5, from the results shown in Table 3 where, the Langmuir constants $q_{m}$ and $K_{L}$ are determined from the slope and intercept of the plot Equation (4) (Figure 6); the $R^{2}>0.999$ values for all adsorbents suggest that the Langmuir isotherms provides a good model of the BTX adsorption, it is observed good fit of the Langmuir equation to the experimental data (Figure 6). The capacities of the aromatics compounds for BTX adsorption are significantly dependent on the temperature and the nature of polycation pillaring ( $\mathrm{Fe} / \mathrm{B}$ and $\mathrm{Fe}-\mathrm{Al} / \mathrm{B}$ ), although the values of $K_{L}$ and $q_{m}$ increase when the temperature is increased about $60^{\circ} \mathrm{C}$ to $80^{\circ} \mathrm{C}$ (Table 3 ). These results also suggest that the BTX interaction must be an endothermic process. The positives $\Delta H^{0}$ (Table 4) value confirms that the adsorption process is endothermic for BTX, which is an indication of the existence of a 


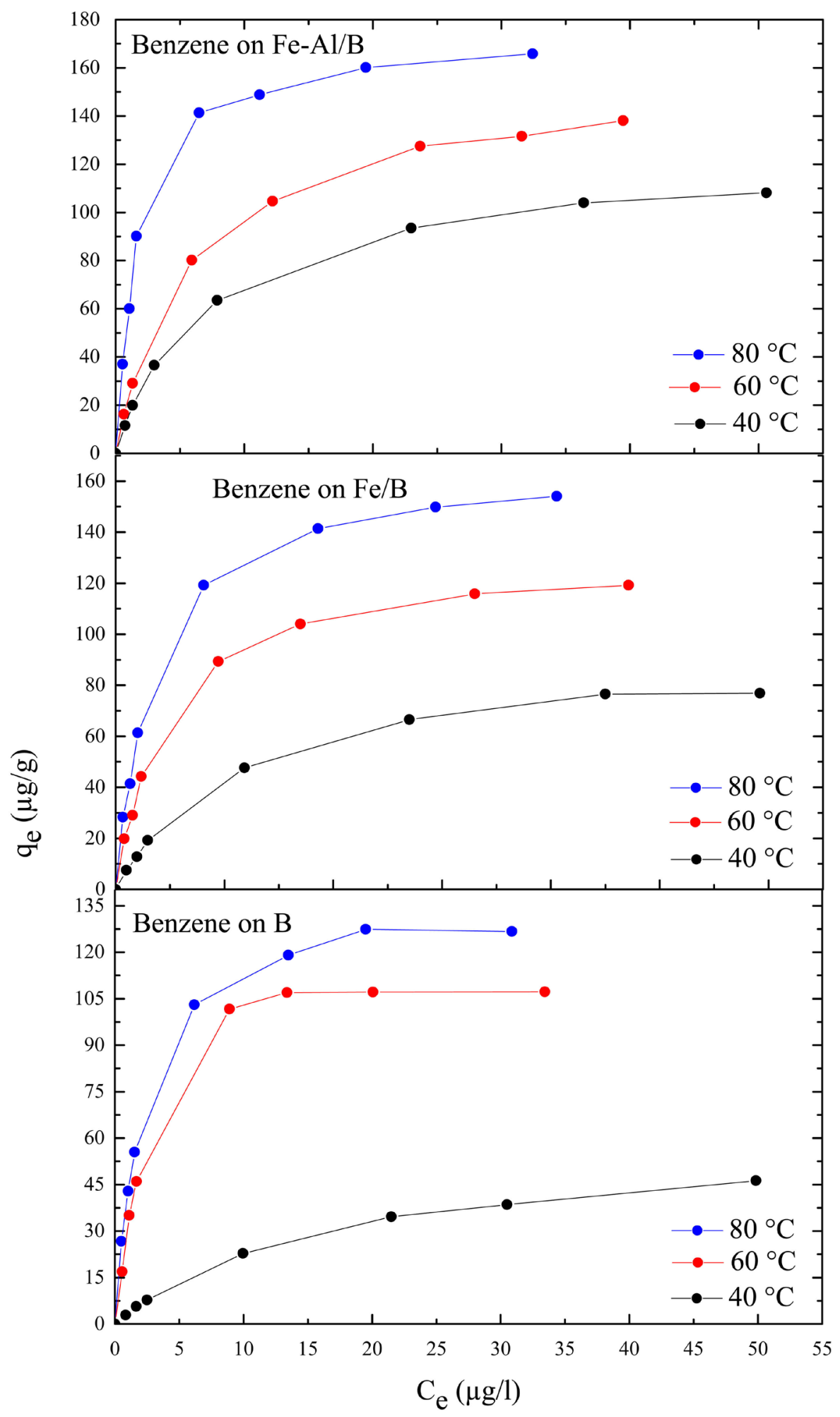




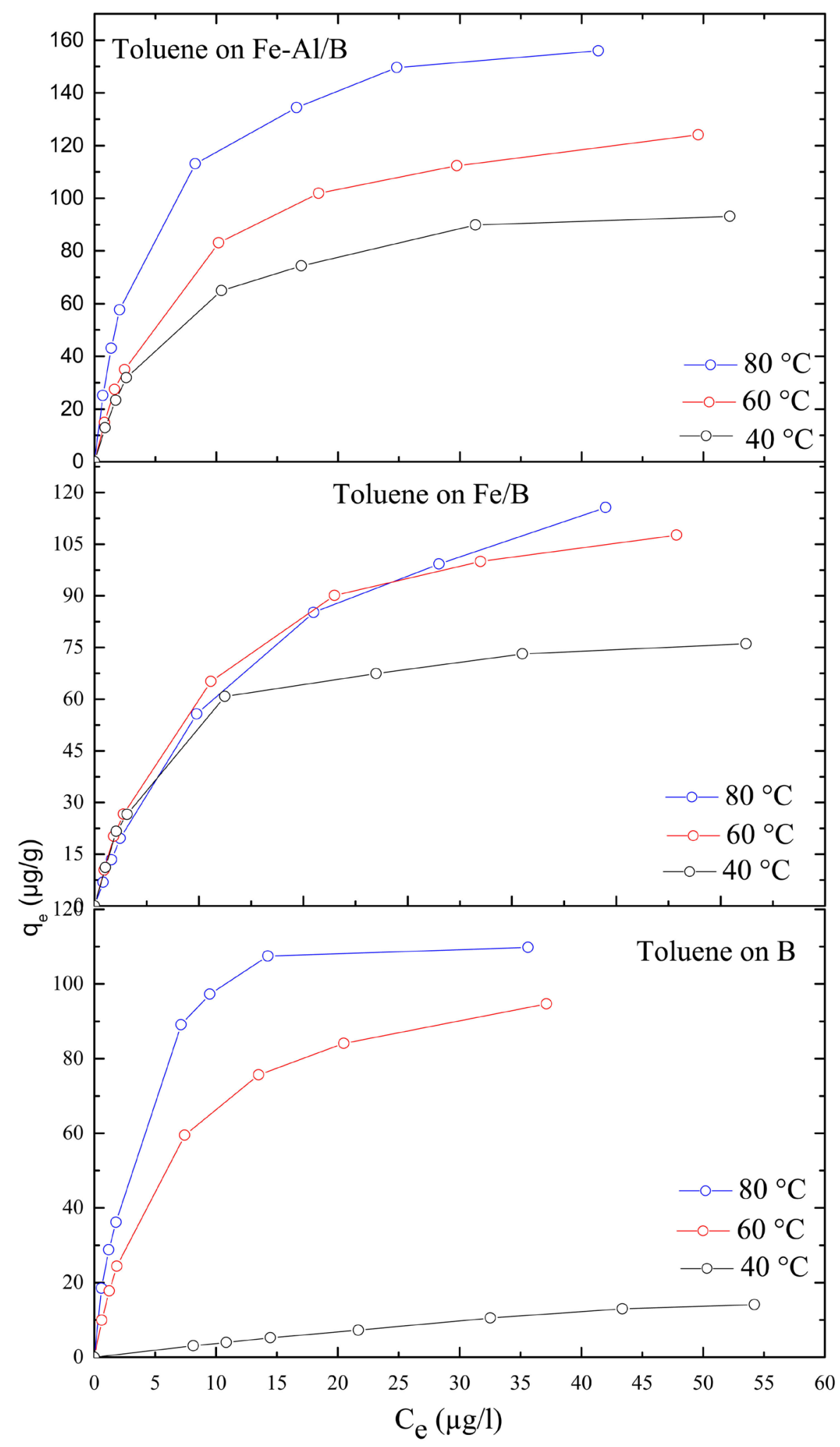




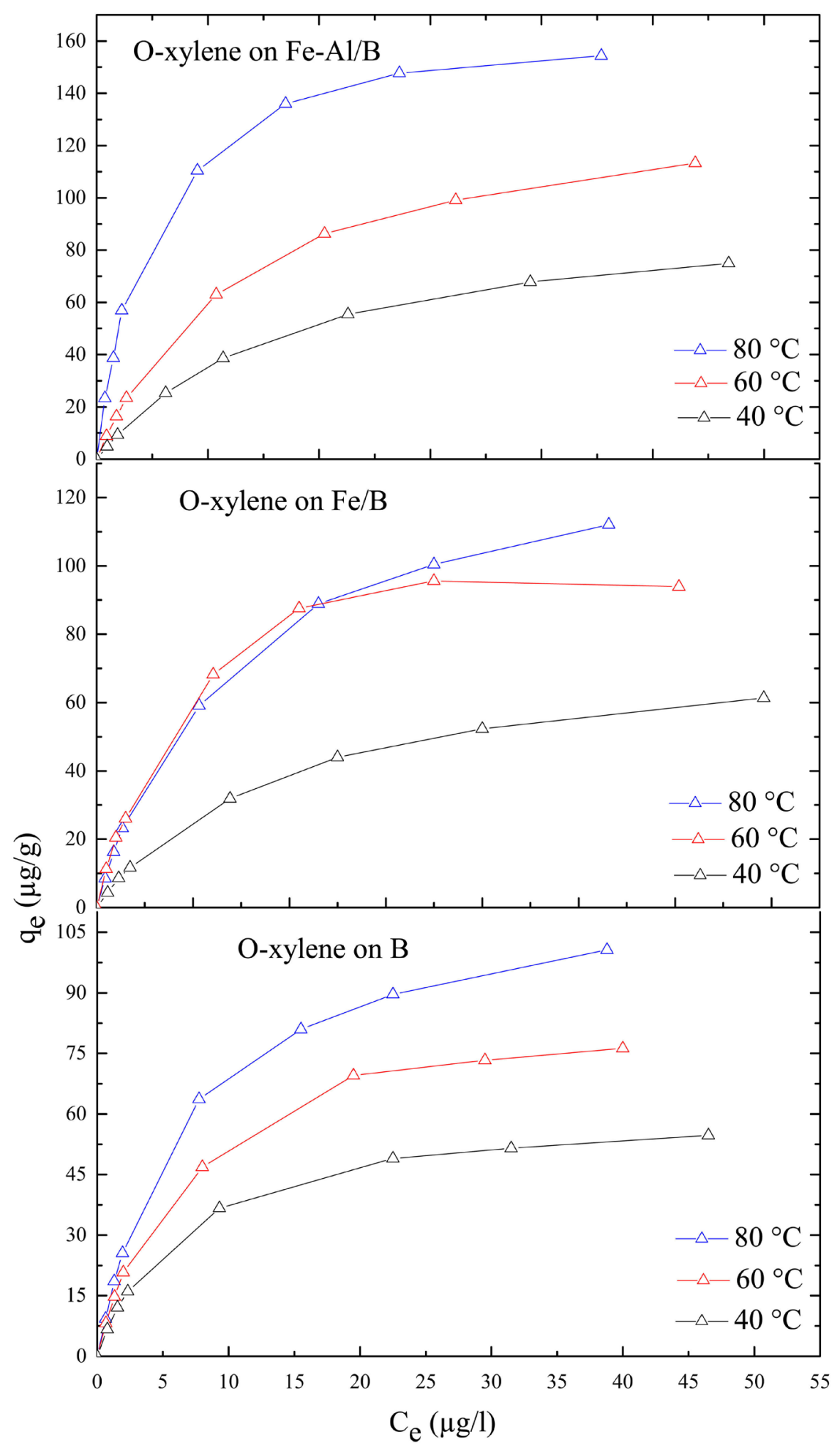

Figure 5. Equilibrium adsorption of BTX onto samples used at various temperature. 
Table 3. Langmuir and Elovitch isotherms constants at different temperatures for the adsorption of BTX onto samples used.

\begin{tabular}{|c|c|c|c|c|c|c|c|c|}
\hline \multirow{2}{*}{ Parameters } & \multicolumn{5}{|c|}{ Langmuir } & \multicolumn{3}{|c|}{ Elovitch } \\
\hline & $T\left({ }^{\circ} \mathrm{C}\right)$ & Sample & $q_{m}(\mu \mathrm{g} / \mathrm{g})$ & $K_{L} \quad(\mathrm{~L} / \mu \mathrm{g})$ & $R^{2}$ & $q_{m} \quad(\mu \mathrm{g} / \mathrm{g})$ & $K_{E} \quad(\mathrm{~L} / \mu \mathrm{g})$ & $R^{2}$ \\
\hline & & B & 70.180 & 0.325 & 0.99 & 66.40 & 0.0149 & 0.99 \\
\hline & 40 & $\mathrm{Fe} / \mathrm{B}$ & 93.540 & 0.017 & 0.99 & 91.32 & 0.0010 & 0.99 \\
\hline & & $\mathrm{Fe}-\mathrm{Al} / \mathrm{B}$ & 123.609 & 0.384 & 0.99 & 115.74 & 0.0086 & 0.99 \\
\hline & & B & 117.500 & 0.425 & 0.99 & 107.17 & 0.0093 & 0.99 \\
\hline \multirow[t]{9}{*}{ Benzene } & 60 & $\mathrm{Fe} / \mathrm{B}$ & 131.750 & 0.421 & 0.99 & 128.35 & 0.0078 & 0.99 \\
\hline & & $\mathrm{Fe}-\mathrm{Al} / \mathrm{B}$ & 157.480 & 0.340 & 0.99 & 149.70 & 0.0066 & 0.99 \\
\hline & & B & 136.990 & 0.474 & 0.99 & 129.61 & 0.0015 & 0.99 \\
\hline & 80 & $\mathrm{Fe} / \mathrm{B}$ & 168.067 & 0.559 & 0.99 & 160.51 & 0.0062 & 0.99 \\
\hline & & $\mathrm{Fe}-\mathrm{Al} / \mathrm{B}$ & 175.130 & 1.089 & 0.99 & 170.35 & 0.0058 & 0.99 \\
\hline & & B & 68.400 & 0.273 & 0.99 & 64.107 & 0.0155 & 0.99 \\
\hline & 40 & $\mathrm{Fe} / \mathrm{B}$ & 83.750 & 0.325 & 0.99 & 80.19 & 0.012 & 0.99 \\
\hline & & $\mathrm{Fe}-\mathrm{Al} / \mathrm{B}$ & 104.710 & 0.323 & 0.99 & 99.18 & 0.0099 & 0.99 \\
\hline & & B & 111.111 & 0.154 & 0.99 & 105.59 & 0.0094 & 0.99 \\
\hline \multirow[t]{9}{*}{ Toluene } & 60 & $\mathrm{Fe} / \mathrm{B}$ & 127.880 & 0.194 & 0.99 & 121.21 & 0.0082 & 0.99 \\
\hline & & $\mathrm{Fe}-\mathrm{Al} / \mathrm{B}$ & 142.850 & 0.275 & 0.99 & 139.66 & 0.0071 & 0.99 \\
\hline & & B & 121.950 & 0.314 & 0.99 & 119.62 & 0.0083 & 0.99 \\
\hline & 80 & $\mathrm{Fe} / \mathrm{B}$ & 155.040 & 0.149 & 0.99 & 149.03 & 0.0067 & 0.99 \\
\hline & & $\mathrm{Fe}-\mathrm{Al} / \mathrm{B}$ & 171.840 & 0.481 & 0.99 & 164.74 & 0.0060 & 0.99 \\
\hline & & B & 62.420 & 0.153 & 0.99 & 58.82 & 0.0016 & 0.99 \\
\hline & 40 & $\mathrm{Fe} / \mathrm{B}$ & 78.430 & 0.102 & 0.99 & 71.42 & 0.014 & 0.99 \\
\hline & & $\mathrm{Fe}-\mathrm{Al} / \mathrm{B}$ & 99.110 & 0.110 & 0.99 & 92.59 & 0.011 & 0.99 \\
\hline & & B & 90.900 & 0.147 & 0.99 & 87.71 & 0.011 & 0.99 \\
\hline \multirow[t]{5}{*}{ O-xylene } & 60 & $\mathrm{Fe} / \mathrm{B}$ & 110.010 & 0.082 & 0.99 & 99.31 & 0.0010 & 0.99 \\
\hline & & $\mathrm{Fe}-\mathrm{Al} / \mathrm{B}$ & 141.640 & 0.150 & 0.99 & 140.84 & 0.0071 & 0.99 \\
\hline & & B & 119.050 & 0.013 & 0.99 & 102.04 & 0.0079 & 0.99 \\
\hline & 80 & $\mathrm{Fe} / \mathrm{B}$ & 140.650 & 0.145 & 0.99 & 136.79 & 0.0073 & 0.99 \\
\hline & & $\mathrm{Fe}-\mathrm{Al} / \mathrm{B}$ & 171.82 & 0.416 & 0.99 & 169.49 & 0.0059 & 0.99 \\
\hline
\end{tabular}




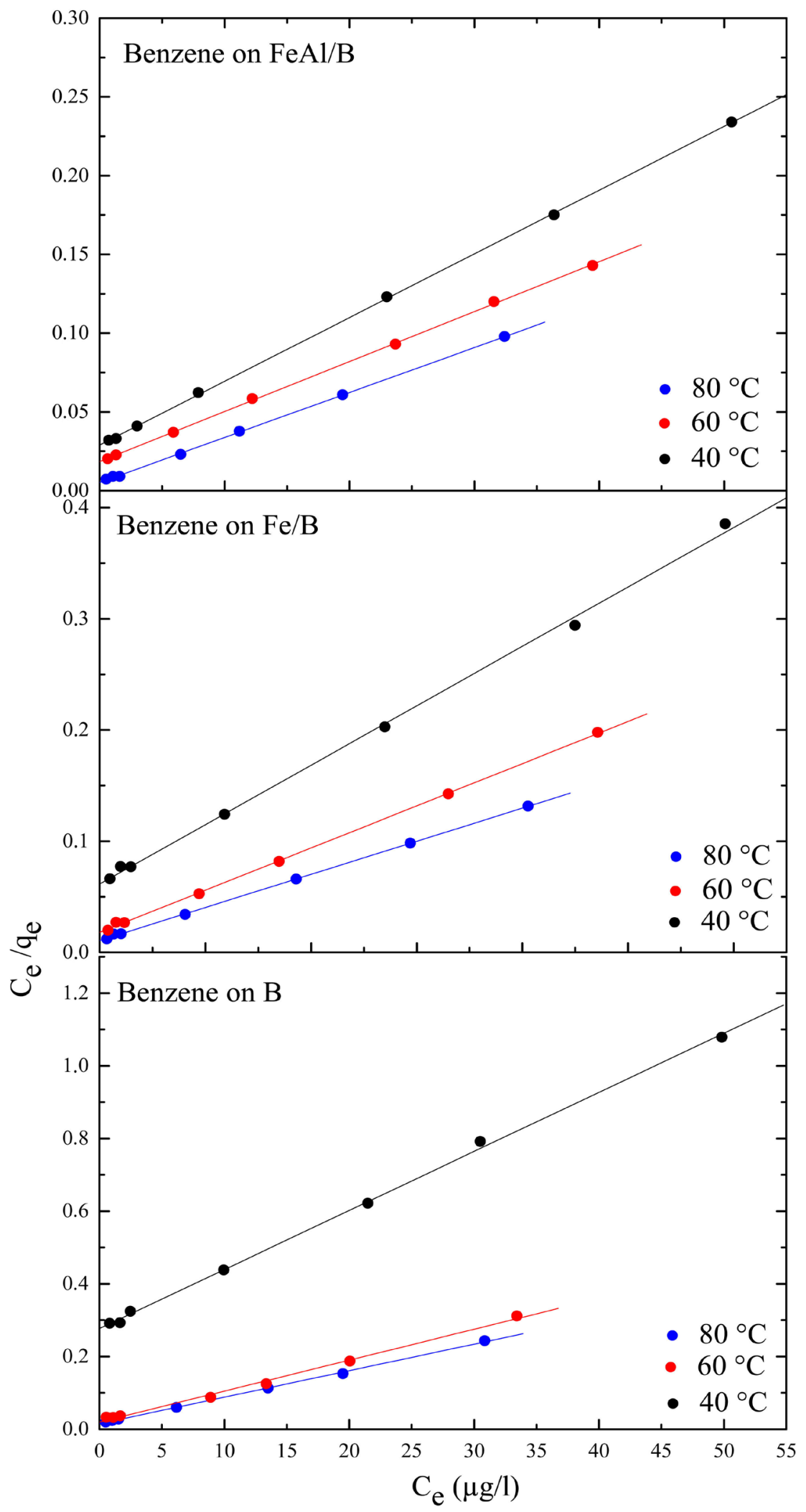




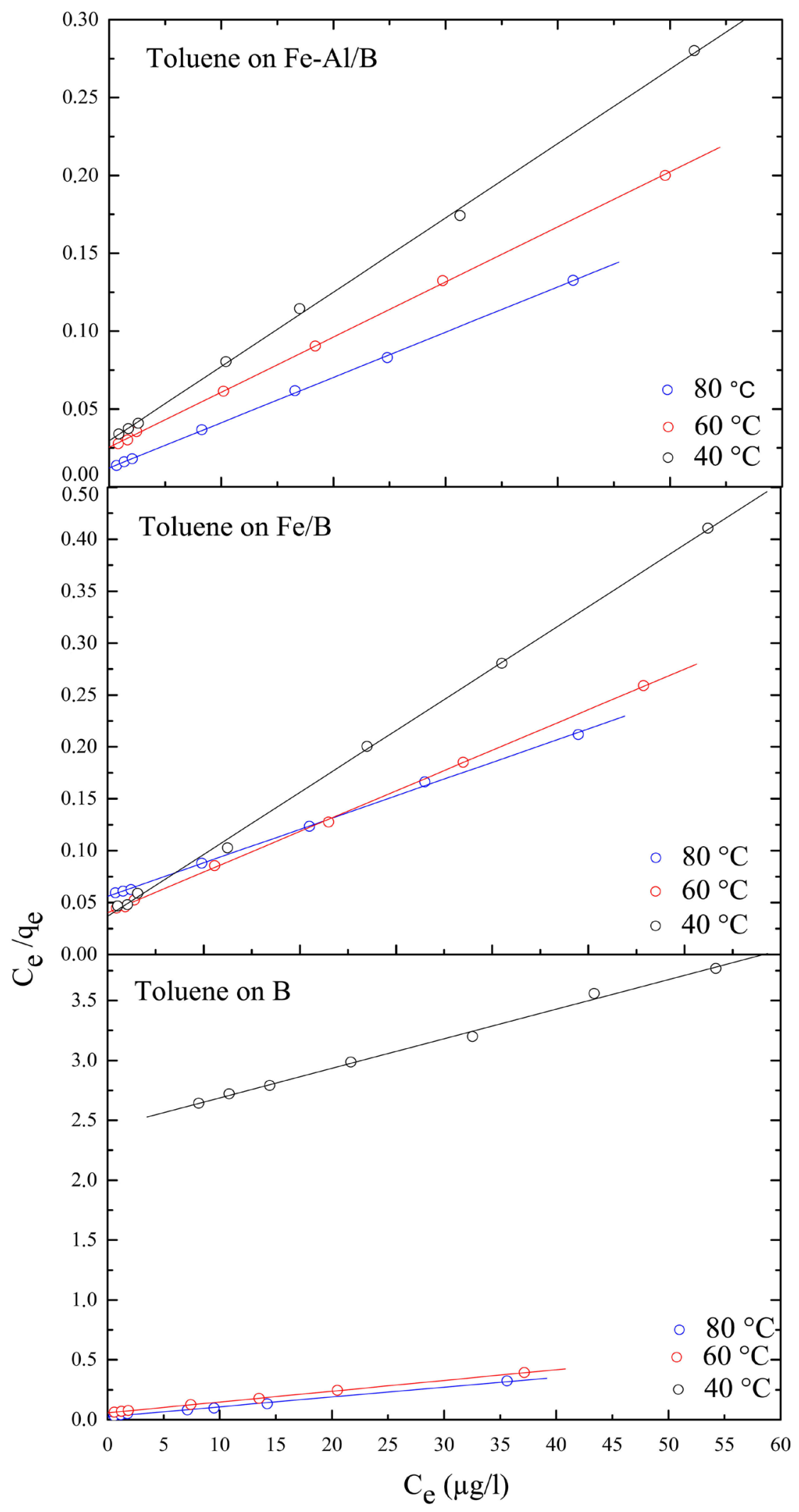




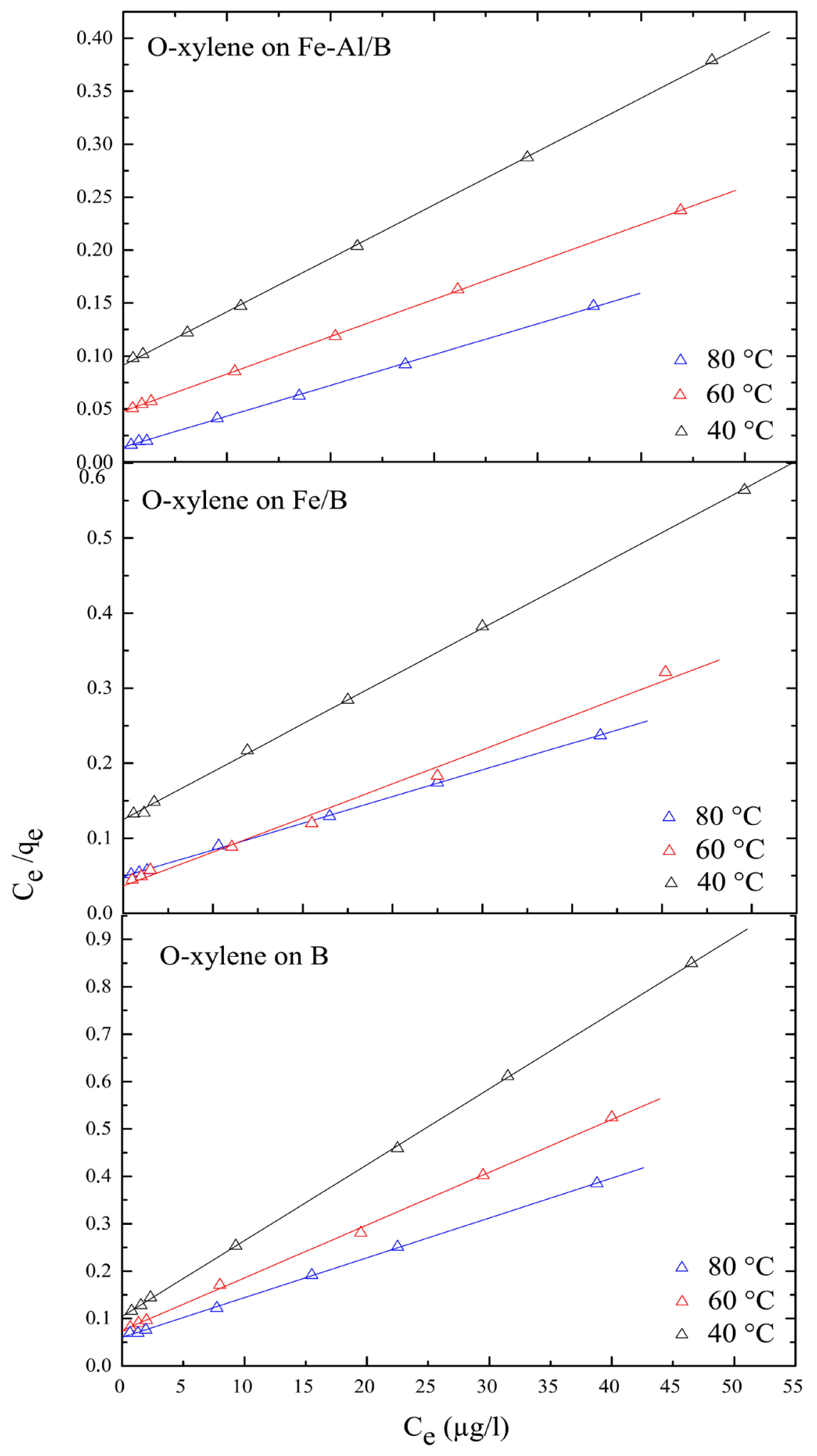

Figure 6. Linear plot Langmuir isotherm of BTX onto samples used at various temperature. 
Table 4. Thermodynamic parameters for the adsorption of BTX onto samples used.

\begin{tabular}{|c|c|c|c|c|c|c|}
\hline \multirow[b]{2}{*}{ Parameters } & \multicolumn{6}{|c|}{ Thermodynamic parameters } \\
\hline & $\pi\left({ }^{\circ} \mathrm{C}\right)$ & Sample & $\Delta G^{0}(\mathrm{KJ} / \mathrm{mo})$ & $\Delta H^{0} \quad(\mathrm{KJ} / \mathrm{mo})$ & $\begin{array}{c}\Delta S^{0} \\
(\mathrm{KJ} / \mathrm{mol})\end{array}$ & $R^{2}$ \\
\hline \multirow{10}{*}{ Benzene } & & B & -6.89 & & & \\
\hline & 40 & $\mathrm{Fe} / \mathrm{B}$ & -14.13 & & & \\
\hline & & $\mathrm{Fe}-\mathrm{Al} / \mathrm{B}$ & -20.61 & & & \\
\hline & & B & -16.49 & & & \\
\hline & 60 & $\mathrm{Fe} / \mathrm{B}$ & -23.15 & & & \\
\hline & & $\mathrm{Fe}-\mathrm{Al} / \mathrm{B}$ & -30.25 & & & \\
\hline & & B & -26.09 & & & \\
\hline & 80 & $\mathrm{Fe} / \mathrm{B}$ & -30.79 & & & \\
\hline & & $\mathrm{Fe}-\mathrm{Al} / \mathrm{B}$ & -38.89 & 119.96 & 0.450 & 0.99 \\
\hline & & B & -2.04 & & & \\
\hline \multirow{7}{*}{ Toluene } & 40 & $\mathrm{Fe} / \mathrm{B}$ & -11.2 & & & \\
\hline & & $\mathrm{Fe}-\mathrm{Al} / \mathrm{B}$ & -21.14 & & & \\
\hline & & B & -11.46 & & & \\
\hline & 60 & $\mathrm{Fe} / \mathrm{B}$ & -18.89 & & & \\
\hline & & $\mathrm{Fe}-\mathrm{Al} / \mathrm{B}$ & -28.15 & & & \\
\hline & & B & -20.25 & & & \\
\hline & 80 & $\mathrm{Fe} / \mathrm{B}$ & -27.1 & & & \\
\hline \multirow{10}{*}{ O-xylene } & & $\mathrm{Fe}-\mathrm{Al} / \mathrm{B}$ & -35.84 & 94.77 & 0.370 & 0.99 \\
\hline & & B & -0.7 & & & \\
\hline & 40 & $\mathrm{Fe} / \mathrm{B}$ & -11.89 & & & \\
\hline & & $\mathrm{Fe}-\mathrm{Al} / \mathrm{B}$ & -19.13 & & & \\
\hline & & B & -9.47 & & & \\
\hline & 60 & $\mathrm{Fe} / \mathrm{B}$ & -20.22 & & & \\
\hline & & $\mathrm{Fe}-\mathrm{Al} / \mathrm{B}$ & -23.44 & & & \\
\hline & & B & -17.43 & & & \\
\hline & 80 & $\mathrm{Fe} / \mathrm{B}$ & -28.02 & & & \\
\hline & & $\mathrm{Fe}-\mathrm{Al} / \mathrm{B}$ & -28.16 & 53.03 & 0.230 & 0.99 \\
\hline
\end{tabular}

strong interaction between all samples used and the molecular structure of these aromatic hydrocarbons compounds. Also, at $80^{\circ} \mathrm{C}$, the maximum capacity $q_{m}$ for the benzene $(175.130 \mu \mathrm{g} / \mathrm{g})$ are higher than those for toluene $(171.84 \mu \mathrm{g} / \mathrm{g})$ and $o$-xylene $(171.82 \mu \mathrm{g} / \mathrm{g})$ by $\mathrm{Fe}-\mathrm{Al} / \mathrm{B}$. Besides, BTX adsorption by B is very low compared to the $\mathrm{Fe} / \mathrm{B}$ and $\mathrm{Fe}-\mathrm{Al} / \mathrm{B}$, (Table 3); the adsorption of benzene is larger than those of toluene and o-xylene, due to the larger surface area in particular $\mathrm{Fe}-\mathrm{Al} / \mathrm{B}\left(355.00 \mathrm{~m}^{2} / \mathrm{g}\right)$ (Table 2). Again, o-xylene and toluene adsorption capacity on $\mathrm{Fe} / \mathrm{B}$ and $\mathrm{Fe}-\mathrm{Al} / \mathrm{B}$ is almost the same at $60^{\circ} \mathrm{C}$ and $80^{\circ} \mathrm{C}$. In this case, the toluene and o-xylene molecules are larger molecules than 
the benzene. Therefore, the adsorption of toluene and o-xylene is more difficult and complicated by microporous adsorbents. The increase of temperature favors this adsorption to occur more easily given that the activation energy can be surmounted more readily. In the case of benzene $\left(\mathrm{C}_{6} \mathrm{H}_{6}\right)$, the smaller size of the molecule leads to easy adsorption without need of large activation energies, this reflects the fact that the kinetic diameter of $\mathrm{C}_{6} \mathrm{H}_{6}$ molecule is smaller than those of toluene and o-xylene [17].

In multilayer adsorption, it is supposed that molecules are adsorbed in several layers on the adsorption surface. One of the equations that predicted multilayer adsorption with unlimited layers is Elovich equation [13]: Equation (5):

$$
(x / m) / q_{m}=K_{E} \cdot C_{e} \cdot \exp \left(-(x / m) / q_{m}\right)
$$

where $x$ and $\mathrm{m}$ are masses of adsorbed and adsorbent respectively, $C_{e}$ is the equilibrium concentration of the adsorbent $(\mu \mathrm{g} / \mathrm{L}) . K_{E}$ and $q_{m}$ are Elovitch equilibrium constant $(\mathrm{L} / \mu \mathrm{g})$ and Elovitch maximum adsorption capacity $(\mu \mathrm{g} / \mathrm{g})$ respectively. Equation (5) can be linearized into the form as follows:

$$
\operatorname{Ln}\left((x / m) / C_{e}\right)=\operatorname{Ln} K_{E} q_{m}+(x / m) / q_{m}
$$

The values of Elovitch maximum adsorption capacity $\left(q_{m}\right)$ and $K_{E}$ are computed the slopes and y-intercepts of the plot $\operatorname{Ln}\left((x / m) / C_{e}\right)$ versus $(x / m)$. The calculated results are shown in Table 3 . The adsorption data of the all samples used is good fitted to the Elovitch equation (Figure 7) with the correlation coefficient $R^{2}>0.99$. The values of maximum adsorption capacity determined using the linear transformation of the Elovich equation (Table 3 ) are higher on $\mathrm{Fe}-\mathrm{Al} / \mathrm{B}$ at $80^{\circ} \mathrm{C}$ for: of benzene $(170.3 \mu \mathrm{g} / \mathrm{g})$, toluene $(164.74 \mu \mathrm{g} / \mathrm{g})$ and $\mathrm{o}-\mathrm{xylene}(169.49 \mu \mathrm{g} / \mathrm{g})$. This means that the assumption of the exponential covering of adsorption sites that implies multilayer adsorption is in agreement with the experiment in the studied concentration range. Therefore, the Elovich model is able to describe the adsorption isotherms of aromatic BTX hydrocarbons.

\subsection{Desorption of BTX}

Figure 8 presented the desorption rate. The results shown that desorption are increased with increase the temperature, at $80^{\circ} \mathrm{C}$ desorption of $\mathrm{Fe}-\mathrm{Al} / \mathrm{B}$ is very quick: and desorption rate of BTX is high $>75 \%$ compared to $\mathrm{Fe} / \mathrm{B}>70 \%$ and $\mathrm{B}>65 \%$. The desorption of the BTX gives results matching those of the adsorption, indeed more than $90 \%$ of the quantities of the BTX are adsorbed on $\mathrm{Fe}-\mathrm{Al} / \mathrm{B}$ at $80^{\circ} \mathrm{C}$.

\subsection{Adsorption Thermodynamics}

In any adsorption process, namely free energy $\left(\Delta G^{0}\right)$, enthalpy $\left(\Delta H^{0}\right)$ and entropy $\left(\Delta S^{0}\right)$ have an important role. The Gibbs free energy change, $\Delta G^{0}$, is an indication of spontaneity of a chemical reaction and therefore an important criterion for spontaneity. Both energy and entropy factors must be considered in order to determine the Gibbs free energy of the process. Reactions occur spontaneously at a given temperature if $\Delta G^{0}$ is a negative quantity. The free energy 


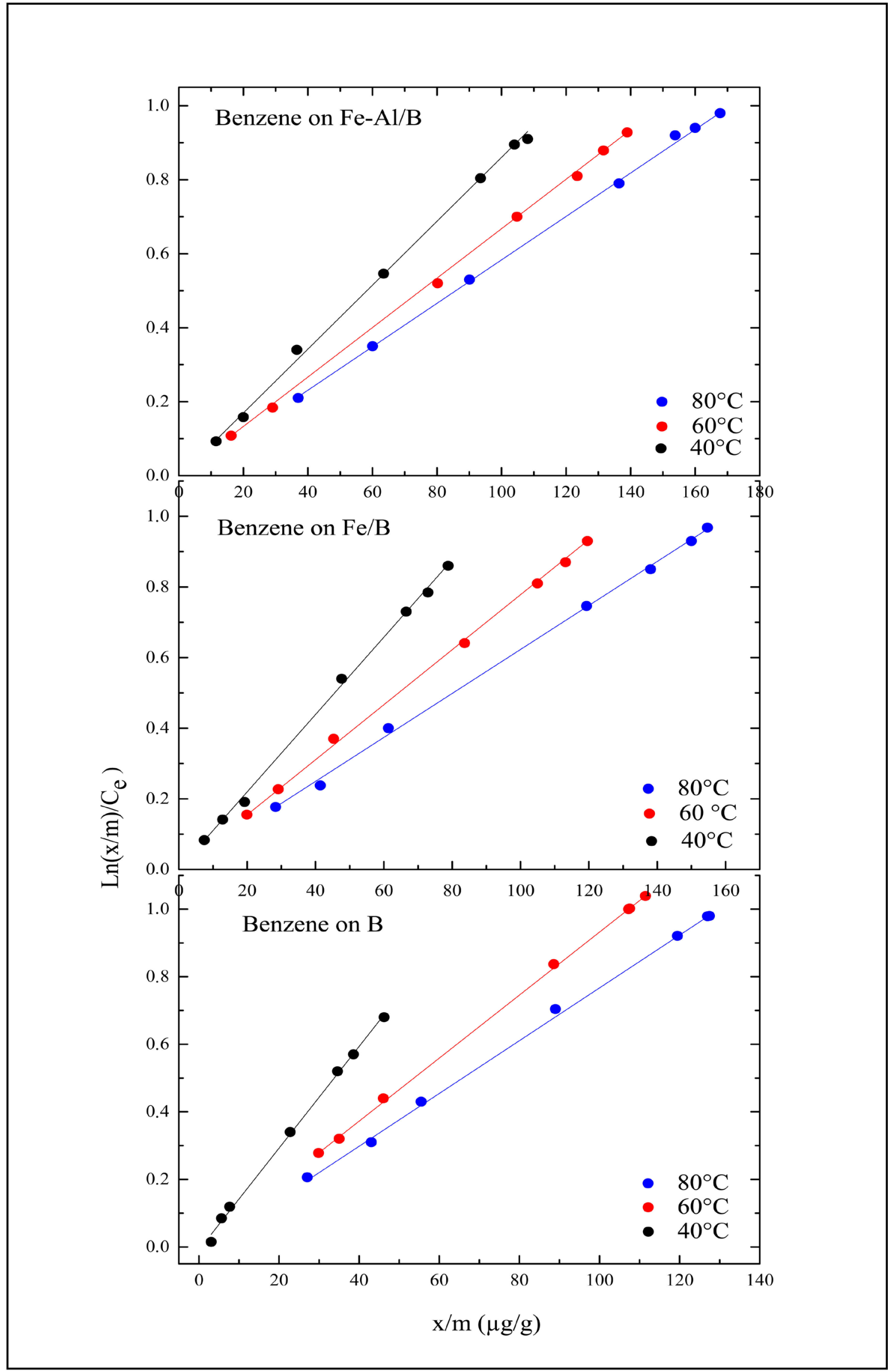




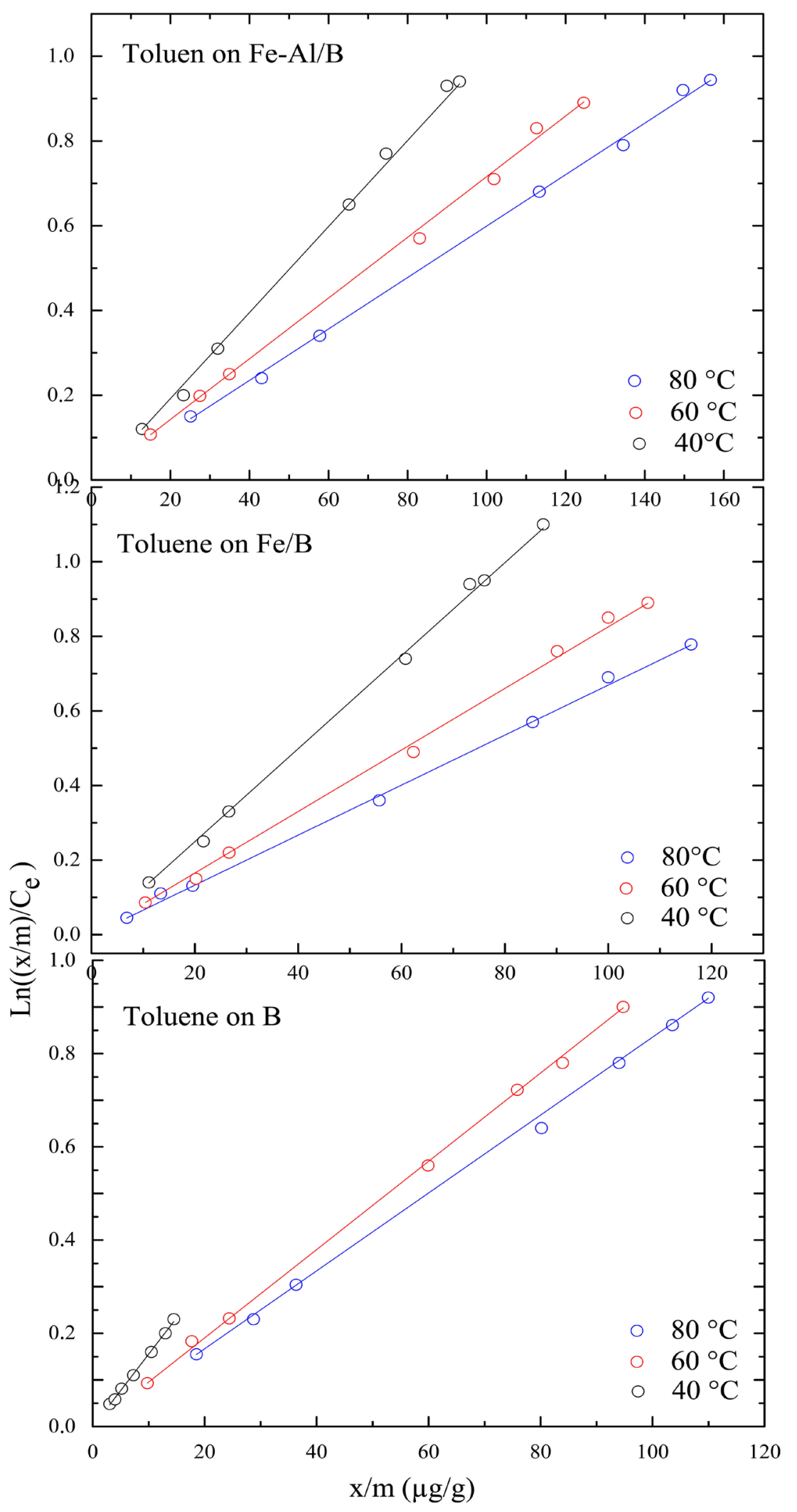




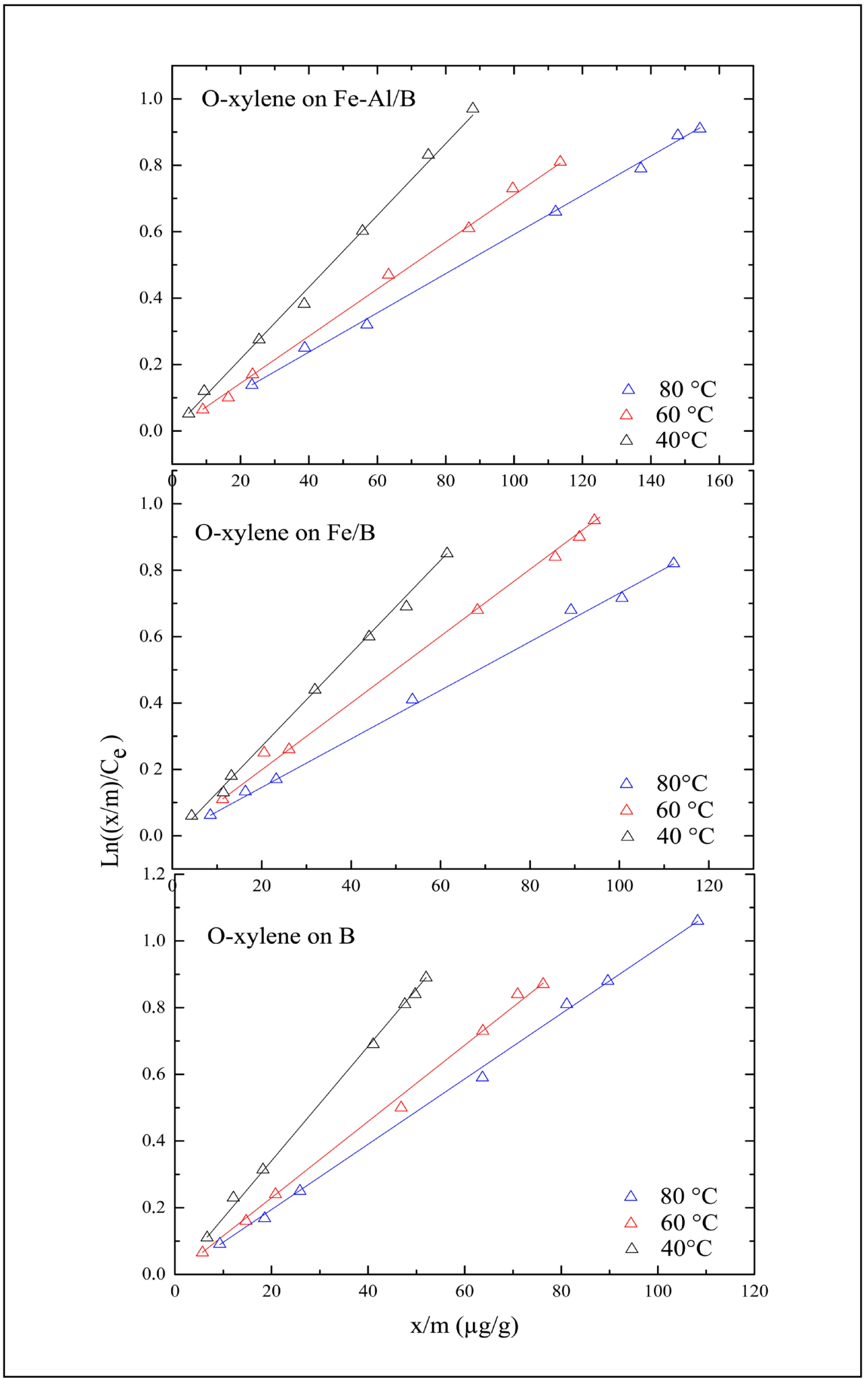

Figure 7. Linear plot Elovitch isotherm of BX onto samples used at various temperature. 


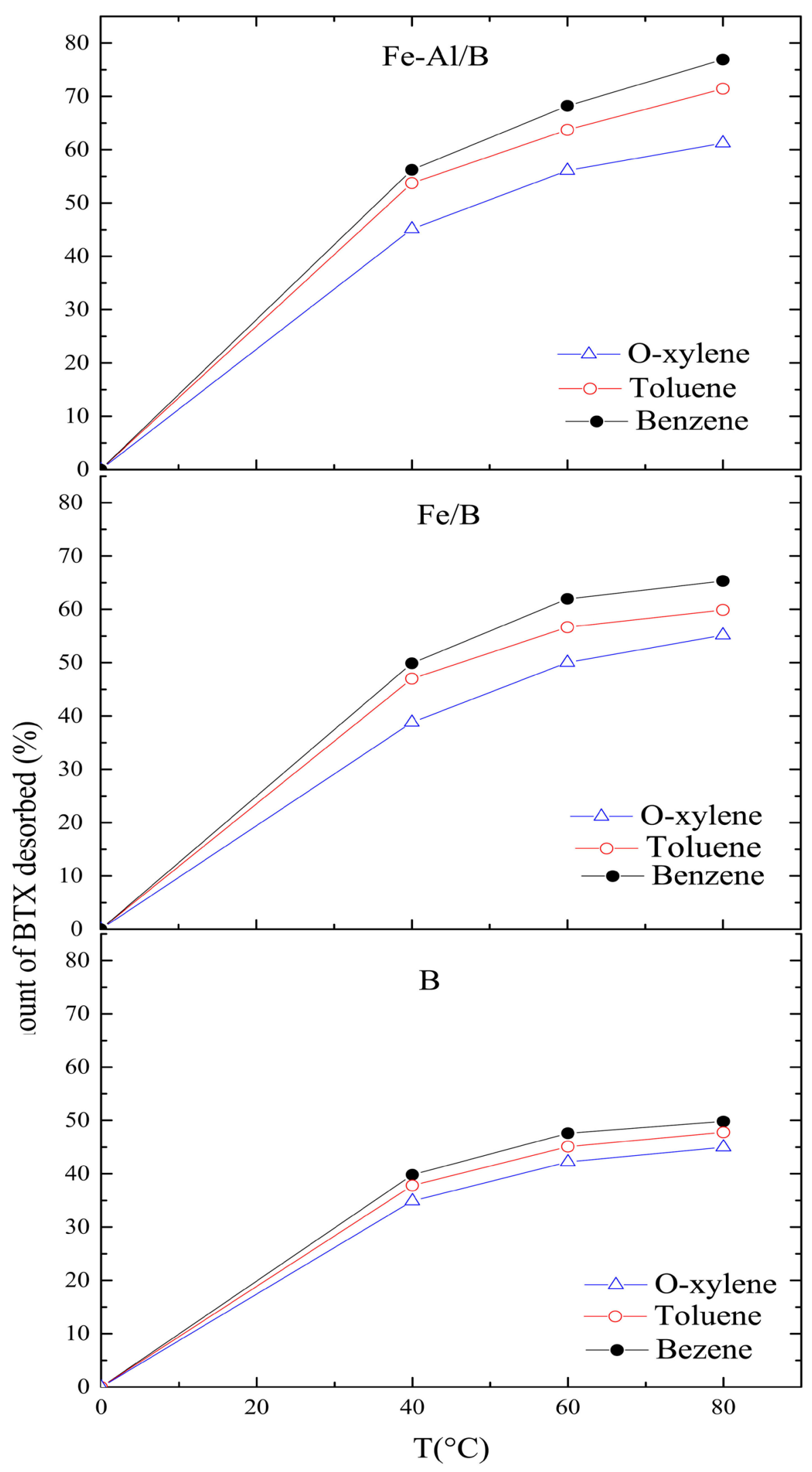

Figure 8. Desorption of BTX onto samples used. 
of an adsorption, considering the adsorption equilibrium constant $K_{d}$ is given by the following equation:

$$
\begin{gathered}
\Delta \mathrm{G}^{0}=-R T \operatorname{Ln} K_{d} \\
K_{d}=\frac{C_{a d s}}{C_{e}}
\end{gathered}
$$

where $\Delta G^{0}$ is the standard free energy change $(\mathrm{J} / \mathrm{mol}), K_{d}$ is the equilibrium constant. $C_{a d s}$ and $C_{e}$ are the equilibrium concentrations $(\mu \mathrm{g} / \mathrm{L})$ of the BTX on the adsorbent used and in the gas phase respectively. $R$ the universal gas constant $(8.314 \mathrm{~J} / \mathrm{mol} \cdot \mathrm{K})$, and $\mathrm{T}$ is the absolute temperature $(\mathrm{K})$. Considering the relationship between $\Delta G^{0}$ and $K_{d}$, change in equilibrium constant with temperature can be obtained in the differential from as follows [18] [19]:

$$
\frac{\mathrm{d} \operatorname{Ln} K_{d}}{\mathrm{~d} T}=\frac{\Delta H^{0}}{R T^{2}}
$$

After integration, the integrated form of Equation (9) becomes:

$$
\operatorname{Ln} K_{d}=-\frac{\Delta H^{0}}{R T}+y
$$

where $Y$ is a constant Equation (10) can be rearranged to obtain;

$$
-R T \operatorname{Ln} K_{d}=\Delta H^{0}-T R Y
$$

Let:

$$
\Delta S^{0}=R Y
$$

Substituting Equation (11) and Equation (12), $\Delta G^{0}$, can be represented as follows:

$$
\Delta G^{0}=\Delta H^{0}-T \Delta S^{0}
$$

The equilibrium constant, $K_{d}$ is obtained from using Equation (6) and Equation (13). A plot of $\Delta G^{0}$ versus $T(\mathrm{~K})$ will be linear and the values of $\Delta H^{0}$ and $\Delta S^{0}$ are determined from the slope and intercept of the plot (Figure 9). The results are presented in Table 4, as it can be seen, at the temperatures of 40 , $60^{\circ} \mathrm{C}$ and $80^{\circ} \mathrm{C}$ the negative values of $\Delta G^{0}$ and positive values of $\Delta H^{0}$ indicate that the adsorption of BTX on all samples used is spontaneous and endothermic process. The positive value of $\Delta S^{0}$ reflects the affinity of the all samples used for BTX and suggests that entropy is responsible for making the $\Delta G^{0}$ negative for the adsorption process to be spontaneous.

\section{Conclusions}

The study of adsorption of aromatic BTX hydrocarbons on $\mathrm{B}, \mathrm{Fe} / \mathrm{B}$ and $\mathrm{Fe}-\mathrm{Al} / \mathrm{B}$ solids has shown that the adsorption of BTX is a function of temperature. The adsorption capacity increased with increasing temperature. The adsorption capacity of purified bentonite and pillared bentonite increases with polycations of $\mathrm{Fe}$ or $\mathrm{Fe}-\mathrm{Al}$ where $\mathrm{Fe}-\mathrm{Al} / \mathrm{B}$ is a good adsorbent with maximum capacity $q_{m}$ for the benzene being $175.30 \mu \mathrm{g} / \mathrm{g}$ at $80^{\circ} \mathrm{C}$; the adsorption isotherms of all BTX aromatic hydrocarbons are favorable at Langmuir model and Elovich 


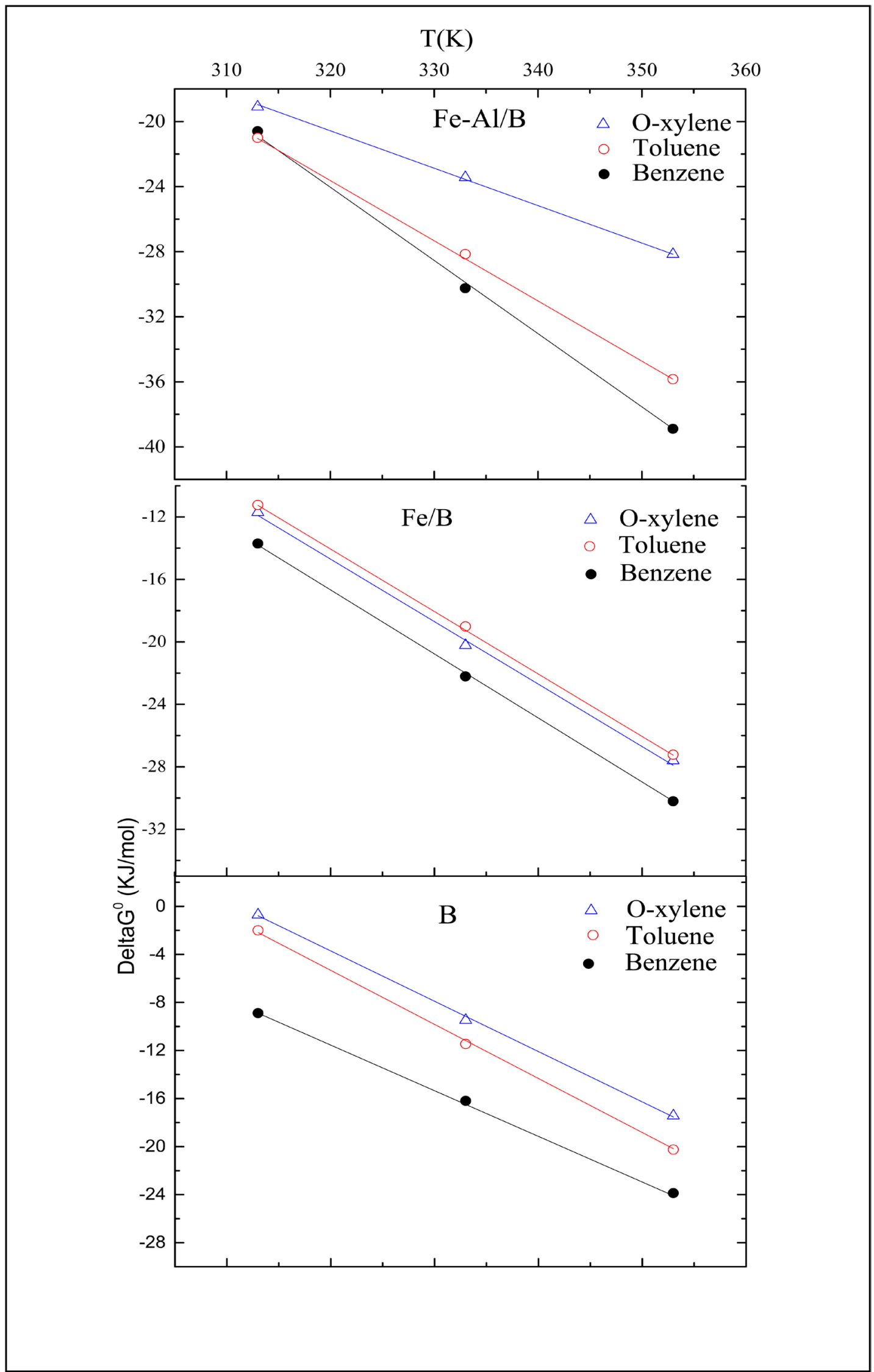

Figure 9. Plot of Gibbs free energy change, $\Delta G^{0}$ various temperature. 
model provides the best fit to the experimental data with high correlation coefficient ( $\left.R^{2}=0.99\right)$.

The adsorption is easy for benzene compared with toluene and $o$-xylene. The Gibbs free energy $\left(\Delta G^{0}\right)$ demonstrated that the adsorption process is favorable for adsorption of all BTX aromatic hydrocarbons by purified bentonite or pillared bentonite and this adsorption is reflected in the positive values of entropy $\left(\Delta S^{0}\right)$.

It may be concluded that pillared bentonite may be used as a low-cost, natural and abundant source for the elimination of aromatic BTX hydrocarbons.

\section{References}

[1] U.S. Environment Protection Agency Office of Air Quality (2000) National Air Toxics Program: The Integrated Urban Strategy. Report to Congress, EPA 453-R99-007. http://www.epa.gov/urban-air-toxics

[2] Kuran, P. and Sojak, L. (1996) Environmental Analysis of Volatile Organic Compounds in Water and Sediment by Gas Chromatography. Journal of Chromatography A, 733, 119-141. http://10.1016/0021-9673(95)01121-8

[3] Alice, O.R. and Emil, D. (2003) Destruction of Volatile Organic Compounds by Catalytic Oxidation. Environmental Engineering and Management Journal, 4, 273 302. http://omicron.ch.tuiasi.ro/EEMJ/

[4] Daifullah, A.A.M. and Girgis, B.S. (2003) Impact of Surface Characteristics of Active Carbon on Adsorption of BTEX. Colloids and Surfaces A: Physicochemical and Engineering, 214, 181-193. https://doi.org/10.1016/S0927-7757(02)00392-8

[5] Blocki, S.W. (1993) Hydrophobic Zeolites Adsorbent: A Proven Advancement in Solvent Separation Technology. Technology Environmental Progress, 12, 226-230. https://doi.org/10.1002/ep.670120312

[6] Egbuchunama, T.O., Obia, G., Okieimenb, F.E. and Tihminliogluc, F. (2016) Removal of BTEX from Aqueous Solution Using Organokaolinite. International Journal of Applied Environmental Sciences, 11, 505-513. http://www.ripublication.com

[7] Carvalho, M.N., Da Motta, M., Benachour, M., Sales, D.C.S. and Abreu, C.A.M. (2012) Evaluation of BTEX and Phenol Removal from Aqueous Solution by Multi-Solute Adsorption onto Smectite Organoclay. Journal of Hazardous Materials, 240, 95-101. https://doi.org/10.1016/j.jhazmat.2012.07.057

[8] Jaynes, W.F. and Vances, G.F. (1999) Sorption of Benzene, Toluene, Ethylbenzene, and Xylene (BTEX) Compounds by Hectorite Clays Exchanged with Aromatic Organic Cations. Clays and Clay Minerals, 47, 358-365. https://doi.org/10.1346/CCMN.1999.0470312

[9] Moura, C.P., Vidal, C.B., Barros, A.L., Costa, L.S., Vasconcellos, L.C.G., Dias, F.S. and Nascimento, R.F. (2011) Adsorption of BTX (Benzene, Toluene, o-Xylene, and p-Xylene) from Aqueous Solutions by Modified Periodic Mesoporous Organosilica. Journal of Colloid Interface Science, 363, 626-634. https://doi.org/10.1016/j.jcis.2011.07.054

[10] Sharmasarkar, S., Jaynes, W.F. and Vance, G.F. (2000) BTEX Sorption by Montmorillonite Organoclay. Water Air Soil Pollution, 119, 257-273. https://doi.org/10.1023/A:1005167524630

[11] Nourmoradi, H., Nikaeen, M. and Khiadani, M. (2012) Removal of Benzene, Toluene, Ethylbenzene and Xylene (BTEX) from Aqueous Solutions by Montmorillonite 
Modified with Non-Ionic Surfactant: Equilibrium, Kinetic and Thermodynamic Study. Chemical Engineering Journal, 191, 341-348.

https://doi.org/10.1016/j.cej.2012.03.029

[12] Méçabih, Z., Kacimi, S. and Bouchikhi, B. (2006) Adsorption des eaux usées urbaines sur la bentonite modifiée par Fe(III), $\mathrm{Al}(\mathrm{III})$ et $\mathrm{Cu}(\mathrm{II})$. Revue Sciences Eaux, 19, 23 31. http://10.7202/012261ar

[13] Méçabih, Z., Rose, J. and Borschneck, D. (2014) Urban Wastewater Treatment by Adsorption of Organic Matters on Modified Bentonite by (Iron-Aluminium). Journal of Encapsulation and Adsorption Sciences, 4, 71-79. https://doi.org/10.4236/jeas.2014.43008

[14] Rauquerol, F., Rauquerol, J. and Sing, K. (1999) Adsorption by Powders and Porous Solids: Principles, Methodology and Application. Academic Press, San Diego.

[15] Barrett, E.P., Joyner, L.G. and Halenda, P.P. (1951) The Determination of Pore Volume and Area Distributions in Porous Substances. I. Computations from Nitrogen Isotherms. Journal of American Chemical Society, 73. 373-380. https://doi.org/10.1021/ja01145a126

[16] Bankovic, P., Milutinovic, N.A., Jovic, J.N., Dostanic, J., Cupic, Z., Loncarevic, D. and Jovanovic, D. (2009) Synthesis, Characterization and Application of AlFe-Pillared. Acta Physica Polonica A, 4, 811-815. https://doi.org/10.12693/APhysPolA.115.811

[17] Hernandez, M.A., Corona, L., Gonzalez, A.I., Rojas, F., Lara, V.H. and Silva, F. (2005) Quantitative Study of the Adsorption Aromatic Hydrocarbons (Benzene, Toluene, and p-Xylene) on Dealuminated Clinoptiloties. Industrial Engineering Chemistry Research, 44, 2908-2916 https://doi.org/10.1021/ie049276w

[18] Song, H., Cheng, W., Jing, H., Fuxing, G. and Ho, Y.S. (2009) Adsorption Thermodynamics of Methylene Blue onto Bentonite. Journal of Hazardous Materials, 167, 630-633. https://doi.org/10.1016/j.jhazmat.2009.01.014

[19] Fei, Y., Jie, M. and Yanqing, W. (2011) Adsorption of Toluene, Ethylbenzene and m-Xylene on Multi-Walled Carbon Nanatubes with Different Oxygen Content from Aqueous Solutions. Journal of Hazardous Materials, 192, 1370-1379. https://doi.org/10.1016/j.jhazmat.2011.06.048

\section{Scientific Research Publishing}

\section{Submit or recommend next manuscript to SCIRP and we will provide best service for you:}

Accepting pre-submission inquiries through Email, Facebook, LinkedIn, Twitter, etc. A wide selection of journals (inclusive of 9 subjects, more than 200 journals)

Providing 24-hour high-quality service

User-friendly online submission system

Fair and swift peer-review system

Efficient typesetting and proofreading procedure

Display of the result of downloads and visits, as well as the number of cited articles

Maximum dissemination of your research work

Submit your manuscript at: http://papersubmission.scirp.org/

Orcontact jeas@scirp.org 